\title{
A multilevel dataset of microplastic abundance in the world's upper ocean and the Laurentian Great Lakes
}

\author{
Atsuhiko Isobe ${ }^{1 *}$, Takafumi Azuma ${ }^{2}$, Muhammad Reza Cordova ${ }^{3}$, Andrés Cózar $^{4}$, Francois Galgani ${ }^{5}$, \\ Ryuichi Hagita ${ }^{6}$, La Daana Kanhai ${ }^{7}$, Keiri Imai ${ }^{8}$, Shinsuke Iwasaki ${ }^{9}$, Shin'ichro Kako ${ }^{10}$, Nikolai Kozlovskii ${ }^{11}$, \\ Amy L. Lusher ${ }^{12,13}$, Sherri A. Mason ${ }^{14}$, Yutaka Michida ${ }^{15}$, Takahisa Mituhasi ${ }^{2}$, Yasuhiro Morii ${ }^{16}$, Tohru Mukai ${ }^{17}$, \\ Anna Popova ${ }^{11}$, Kenichi Shimizu ${ }^{18}$, Tadashi Tokai ${ }^{19}$, Keiichi Uchida ${ }^{19}$, Mitsuharu Yagi ${ }^{18}$ and Weiwei Zhang ${ }^{20}$
}

\begin{abstract}
A total of 8218 pelagic microplastic samples from the world's oceans were synthesized to create a dataset composed of raw, calibrated, processed, and gridded data which are made available to the public. The raw microplastic abundance data were obtained by different research projects using surface net tows or continuous seawater intake. Fibrous microplastics were removed from the calibrated dataset. Microplastic abundance which fluctuates due to vertical mixing under different oceanic conditions was standardized. An optimum interpolation method was used to create the gridded data; in total, there were 24.4 trillion pieces ( $8.2 \times 10^{4} \sim 57.8 \times 10^{4}$ tons) of microplastics in the world's upper oceans.
\end{abstract}

Keywords: Microplastic abundance, 2D maps in the world's ocean, Multilevel dataset

\section{Introduction}

Microplastics are being reported globally, but it is challenging to compare the data collected when different methods and reporting criteria are followed (e.g., [1]). Harmonized or standardized protocols are therefore recommended for collecting data in the future [2, 3]. Data collected by previous studies are still valuable and efforts to critically compare and evaluate these data are urgently needed. Laboratory-based studies on damage to aquatic organisms exposed to microplastics might be inaccurate if microplastic concentration (e.g., weight per unit water volume) estimates are much larger than the reality [4]. Analyzing microplastic abundance by synthesizing observation data from various oceanic basins will be helpful to bridge a gap between the laboratory-based studies and threats in reality. Similarly, real data on microplastic

\footnotetext{
* Correspondence: aisobe@riam.kyushu-u.ac.jp

${ }^{1}$ Research Institute for Applied Mechanics, Kyushu University, 6-1

Kasuga-Koen, Kasuga 816-8580, Japan

Full list of author information is available at the end of the article
}

abundance in the oceans is needed to validate the accuracy of numerical models (e.g., [5, 6]).

A few studies have synthesized microplastic abundance data for the world's oceans to generate datasets. Eriksen et al. [7] created a publicly available dataset of microplastic abundance based on data obtained from 680 surface net tows conducted by different researchers during 2007-2013. These data were standardized to reduce uncertainty derived from vertical mixing induced by oceanic turbulence, because abundance estimates based on surface net tows are influenced by oceanic conditions: particle counts for light-weight microplastics, which are produced mostly from polyethylene and polypropylene (polymers less dense than seawater, [8]), decrease (or increase) near the sea surface under stormy (or calm) oceanic conditions. They used a formula to estimate the vertical distribution of the particle counts [9], to deduce the total particle count throughout the entire water column under wind speeds measured on the Beaufort scale. However, no description of the significant

\section{Springer Open}

(ㅇ The Author(s). 2021 Open Access This article is licensed under a Creative Commons Attribution 4.0 International License, which permits use, sharing, adaptation, distribution and reproduction in any medium or format, as long as you give appropriate credit to the original author(s) and the source, provide a link to the Creative Commons licence, and indicate if changes were made. The images or other third party material in this article are included in the article's Creative Commons licence, unless indicated otherwise in a credit line to the material. If material is not included in the article's Creative Commons licence and your intended use is not permitted by statutory regulation or exceeds the permitted use, you will need to obtain permission directly from the copyright holder. To view a copy of this licence, visit http://creativecommons.org/licenses/by/4.0/. 
wave heights required for the formula was provided in Eriksen et al. [7]. Cózar et al. [10] synthesized microplastic abundance data obtained from 841 surface net tows (442 wind-corrected samples), including a circumnavigation cruise of the earth. Published and unpublished microplastic abundance data from 1979 through 2013 (11,632 samples in total) were synthesized by van Sebille et al. [6], although their dataset was not made available to the public. They statistically standardized the data obtained by different researchers using a generalized additive model incorporating the year in which each study was conducted, the geographical locations, and wind speeds given by an atmospheric reanalysis product.

Here, we provide a new dataset of pelagic microplastic abundance in the world's oceans which incorporates different sampling methods. The dataset includes both published and unpublished microplastic abundance data obtained from 2000 to 2019. The number of samples is $\sim 10$-fold $(n=8218)$ higher than Eriksen et al. [7] and Cózar et al. [10]. We standardized the data obtained by different researchers in a physical manner. The dataset is publicly available as the Supplementary data in a CSV format.

\section{Methods -description of the dataset Categorization of data}

Different from the datasets mentioned above, the data in the present study were categorized as raw, calibrated, processed, and gridded data, similar to satellite products (https://climatedataguide.ucar.edu/climatedata/nasa-satellite-product-levels). Raw data (hereinafter referred to as Level-0 data) were mostly obtained by surface net tows and are provided as "particle count per unit seawater volume (partly, per unit area)". First, these raw data were calibrated to the abundance of microplastics $(<5 \mathrm{~mm})$, except fibrous microplastics (filaments and fibers), as a quality control (Level 1). Second, to reduce uncertainty derived from vertical mixing, integrating microplastic abundance vertically from the sea surface to the infinitely deep layer yielded processed data for both the total particle count (Level $2 \mathrm{p}$ ) and weight (Level $2 \mathrm{w}$ ), over the entire water column per unit area, where the subscripts ' $p$ ' and ' $w$ ' represent the particle count and weight, respectively. Third, the Level- $2 \mathrm{p}$ and $-2 \mathrm{w}$ data were gridded to obtain the particle counts (Level 3p) and weight (Level $3 \mathrm{w}$ ) per unit area using an optimum interpolation method (OIM). Last, these gridded data were converted to monthly particle counts (Level 3 pm; 'm' represents monthly data) and weights (Level $3 \mathrm{wm}$ ) per unit seawater volume in the uppermost layer. The present paper describes the detailed procedures to create this multilevel dataset.

\section{Level 0 -raw data}

Data from 27 research projects conducted during the period from 2000 through 2019 (Table 1) were used to create the Level-0 data on pelagic microplastic abundance in the world's oceans and the Laurentian Great Lakes. We synthesized the data collected during the past 20 years to represent the 'current status' of microplastic abundance, because a long-term trend is undetectable in such a short period, as shown by Law et al. [26], who provided a time series of plastic-debris abundance from 1986 to 2008, and because long term change is not a common scheme for floating plastics and microplastics [11, 26, 33-35]. In total, 23 of the 27 projects collected microplastics only by surface net towing, but Projects \#13 and \#26 (Table 1) collected data via continuous seawater intake at a depth of $3 \mathrm{~m}$ (\#12 partly included seawater intake; Table 1): Nonetheless, the target of these two projects was microplastics over several tens of $\mu \mathrm{m}$ in size (see 'Mesh size' in Table 1). Thus, as defined in the present study, the surface layer included seawater from the sea surface to a depth of $3 \mathrm{~m}$. The Projects \#25 and \#27 collected data via continuous seawater intake at the depth deeper than $3 \mathrm{~m}$, so that these data were included only in the Level-0 and Level-1 (shown next) data. The number of samples obtained after 2014 was smaller than that before 2014, but observations were conducted over all seasons (Supplementary Fig. 1).

Except for duplicated data (the same location, time/ date/year, and observer) which were removed because of no relation to dataset reliability, we used all data obtained by these 27 projects to ensure that the amount thereof was sufficiently large, although parts of these projects adopted procedures that differed from the latest guidelines. Almost all projects adopted a tow net with a mesh size of $0.2-0.3 \mathrm{~mm}$ to collect floating objects, including microplastics. The maximum size of the plastic debris was not recorded in the majority of the projects. We here assumed that plastic debris reported in all projects listed in Table 1 was categorized as microplastics $(<5 \mathrm{~mm}$, as per [8]) unless otherwise stated. This assumption is justified because, for instance, more than $90 \%$ of the plastic debris particles collected by surface net tows in Project \#9 were $<5 \mathrm{~mm}$. Likewise, microplastics $(<5 \mathrm{~mm})$ accounted for $>93.7 \%$ of all particles in Project \#3 despite the upper size limit of $50 \mathrm{~mm}$ in collecting plastic fragments (Supplementary Figure 2). Nine projects conducted surface net tows without a flowmeter, and measured the seawater volume passing through the net (Table 1). The absence of a flowmeter may have led to alternations in the volume passing through the net by ocean currents at towing speeds of 2 $\sim 3$ knots. However, a large amount of data was averaged, which can be expected to reduce the deviations due to ambient ocean currents flowing in different 
Table 1 Data sources and measurement procedures

\begin{tabular}{|c|c|c|c|c|c|c|c|c|c|}
\hline $\begin{array}{l}\text { Project } \\
\text { No. }\end{array}$ & Reference & Area & $\begin{array}{l}\text { Sampling } \\
\text { method }\end{array}$ & $\begin{array}{l}\text { Mesh } \\
\text { size } \\
{[\mathrm{mm}]}\end{array}$ & $\begin{array}{l}\text { Number } \\
\text { of data }\end{array}$ & $\begin{array}{l}\text { Without } \\
\text { fiber (\%) }\end{array}$ & Flowmeter & Identification & Unit \\
\hline (1) & Law et al. [11] & eastern North Pacific & $N^{a}$ & 0.335 & 2529 & $N R^{\mathbf{b}}$ & $\mathrm{W} / \mathrm{O}^{\mathrm{c}}$ & $V^{d}$ & $\begin{array}{l}\text { pieces/ } \\
\mathrm{km}^{2}\end{array}$ \\
\hline (2) & $\begin{array}{l}\text { TN Umitaka, Japan } \\
\text { (unpublished) }^{\mathbf{e}}\end{array}$ & $\begin{array}{l}\text { Southern Ocean, } \\
\text { Pacific }\end{array}$ & N & 0.35 & 128 & $100^{f}$ & $W^{g}$ & FTIR & $\begin{array}{l}\text { pieces/ } \\
\mathrm{m}^{3}\end{array}$ \\
\hline (3) & $\begin{array}{l}\text { Ministry of the Environment, } \\
\text { Japan (unpublished) }\end{array}$ & East Asian seas & N & 0.35 & 312 & $100^{f}$ & W & FTIR & $\begin{array}{l}\text { pieces/ } \\
\mathrm{m}^{3}\end{array}$ \\
\hline (4) & Collignon et al. [12] & the Mediterranean & $W^{i}$ & 0.2 & 38 & $N R$ & W/O & V & $\begin{array}{l}\text { pieces/ } \\
100 \mathrm{~m}^{2}\end{array}$ \\
\hline (5) & Cózar et al. [10] & world's ocean & N & 0.2 & 194 & $100^{f}$ & W & V & $\begin{array}{l}\text { pieces/ } \\
\mathrm{km}^{2}\end{array}$ \\
\hline (6) & Cózar et al. [13] & the Mediterranean & $N$ & 0.2 & 39 & 93.6 & W & V & $\mathrm{g} / \mathrm{km}^{2}$ \\
\hline (7) & Cózar et al. [14] & Arctic Ocean & $M^{j}$ & 0.5 & 42 & $100^{f}$ & W/O & V & $\begin{array}{l}\text { pieces/ } \\
\mathrm{km}^{2}\end{array}$ \\
\hline (8) & Doyle et al. [15] & Bering Sea & M & 0.505 & 271 & 80 & W & FTIR & $\begin{array}{l}\text { pieces/ } \\
\mathrm{m}^{3}\end{array}$ \\
\hline (9) & Eriksen et al. [7] & world's ocean & $\mathrm{N}$ & 0.33 & 679 & $100^{k}$ & W/O & V & $\begin{array}{l}\text { pieces/ } \\
\mathrm{km}^{2}\end{array}$ \\
\hline (10) & Goldstein et al. [16] & eastern North Pacific & N & 0.333 & 147 & $100^{k}$ & W & V & $\begin{array}{l}\text { pieces/ } \\
\mathrm{m}^{3}\end{array}$ \\
\hline (11) & de Lucia et al. [17] & the Mediterranean & M & 0.5 & 4 & NR & W & V & $\begin{array}{l}\text { pieces/ } \\
\mathrm{m}^{3}\end{array}$ \\
\hline (12) & Lusher et al. [18] & Arctic Ocean & $M \& I^{m}$ & 0.333 & 21 & $100^{\prime}$ & W & FTIR & $\begin{array}{l}\text { pieces/ } \\
\mathrm{m}^{3}\end{array}$ \\
\hline (13) & Lusher et al. [19] & $\begin{array}{l}\text { eastern North } \\
\text { Atlantic }\end{array}$ & 1 & $0.25^{n}$ & 652 & 4 & - & Raman & $\begin{array}{l}\text { pieces/ } \\
\mathrm{m}^{3}\end{array}$ \\
\hline (14) & Pan et al. [20] & western North Pacific & M & 0.33 & 18 & 91.1 & W/O & Raman & $\begin{array}{l}\text { pieces/ } \\
\mathrm{km}^{2}\end{array}$ \\
\hline (15) & Pedrotti et al. [21] & the Mediterranean & M & 0.33 & 33 & 100 & W/O & FTIR & $\begin{array}{l}\text { pieces/ } \\
\mathrm{km}^{2}\end{array}$ \\
\hline (16) & Reisser et al. [22] & $\begin{array}{l}\text { Waters around } \\
\text { Australia }\end{array}$ & $N \& M$ & 0.33 & 57 & 93.6 & W/O & FTIR & $\begin{array}{l}\text { pieces/ } \\
\mathrm{km}^{2}\end{array}$ \\
\hline (17) & Suaria, G., C. G., et al. [23] & the Mediterranean & $\mathrm{N}$ & 0.2 & 74 & $100^{f}$ & W & FTIR & $\begin{array}{l}\text { pieces/ } \\
\mathrm{m}^{3}\end{array}$ \\
\hline (18) & Zhang et al. [24] & Bohai Sea & M & 0.33 & 11 & 73 & W & FTIR & $\begin{array}{l}\text { pieces/ } \\
\mathrm{m}^{3}\end{array}$ \\
\hline (19) & Zhao et al. [25] & East China Sea & $\mathrm{N}$ & 0.333 & 15 & 16.8 & W/O & V & $\begin{array}{l}\text { pieces/ } \\
\mathrm{m}^{3}\end{array}$ \\
\hline (20) & Law et al. [26] ${ }^{\circ}$ & $\begin{array}{l}\text { western North } \\
\text { Atlantic \& Caribbean } \\
\text { Sea }\end{array}$ & N & 0.335 & 2280 & NR & W/O & V & $\begin{array}{l}\text { pieces/ } \\
\mathrm{km}^{2}\end{array}$ \\
\hline (21) & Mason et al. [27] & Lakes Erie \& Ontario & M & 0.333 & 130 & 98 & W & FTIR & $\begin{array}{l}\text { pieces/ } \\
\mathrm{km}^{2}\end{array}$ \\
\hline (22) & $\begin{array}{l}\text { Indonesian Institute of Science } \\
\text { (unpublished) }\end{array}$ & Java Sea & N & 0.35 & 16 & $N R$ & W & FTIR & $\begin{array}{l}\text { pieces/ } \\
\mathrm{m}^{3}\end{array}$ \\
\hline (23) & Ifremer (unpublished) & $\begin{array}{l}\text { eastern North } \\
\text { Atlantic \& the } \\
\text { Mediterranean }\end{array}$ & $M \& B^{p}$ & 0.3 & 256 & NR & W & FTIR & $\begin{array}{l}\text { pieces/ } \\
\mathrm{m}^{3}\end{array}$ \\
\hline (24) & $\begin{array}{l}\text { Pacific Geographical Institute \& } \\
\text { Maritime State Univ. } \\
\text { (unpublished) }\end{array}$ & Sea of Japan & $N \& p^{q}$ & 0.1 & 21 & $100^{\prime}$ & W & FTIR & $\begin{array}{l}\text { pieces/ } \\
\mathrm{m}^{3}\end{array}$ \\
\hline (25) & Kanhai et al. [28] ${ }^{\mathbf{r}}$ & eastern Atlantic & I & 0.25 & 76 & $0 \sim 100^{s}$ & - & FTIR & $\begin{array}{l}\text { pieces/ } \\
\mathrm{m}^{3}\end{array}$ \\
\hline
\end{tabular}


Table 1 Data sources and measurement procedures (Continued)

\begin{tabular}{|c|c|c|c|c|c|c|c|c|c|}
\hline $\begin{array}{l}\text { Project } \\
\text { No. }\end{array}$ & Reference & Area & $\begin{array}{l}\text { Sampling } \\
\text { method }\end{array}$ & $\begin{array}{l}\text { Mesh } \\
\text { size } \\
{[\mathrm{mm}]}\end{array}$ & $\begin{array}{l}\text { Number } \\
\text { of data }\end{array}$ & $\begin{array}{l}\text { Without } \\
\text { fiber (\%) }\end{array}$ & Flowmeter & Identification & Unit \\
\hline (26) & Yakushev et al. [29] & Arctic Ocean & $N \& I$ & $\begin{array}{l}0.2, \\
0.1^{t}\end{array}$ & 108 & $0 \sim 100$ & W/O & $\mathrm{FTIR}, \mu \mathrm{FTIR}$ & $\begin{array}{l}\text { pieces/ } \\
\mathrm{m}^{3}\end{array}$ \\
\hline (27) & Kanhai et al. [30] ${ }^{\mathbf{v}}$ & Arctic Ocean & 1 & 0.25 & 58 & 0 & - & FTIR & $\begin{array}{l}\text { pieces/ } \\
\mathrm{m}^{3}\end{array}$ \\
\hline
\end{tabular}

${ }^{\mathbf{a}}$ Neuston net, ${ }^{\mathbf{b}}$ Not recorded, ${ }^{\mathbf{C}}$ Without a flowmeter, ${ }^{\mathbf{d}}$ Visual identification, ${ }^{\mathbf{e}}$ Partly published in Isobe et al. [31] and Isobe et al. [5], ${ }^{\mathbf{f}}$ Fibrous microplastics were discarded by this project., ${ }^{\mathbf{9}}$ With a flowmeter, ${ }^{\mathbf{h}}$ Partly published in Isobe et al. [32], ${ }^{\mathbf{i}}$ WP2 net, ${ }^{\mathbf{j}}$ Manta net, ${ }^{\mathbf{k}}$ The authors stated that the "vast majority" of collected microplastics were fragments. ' The abundance without fibrous microplastics was provided by the coauthor. ${ }^{\mathbf{m}}$ Intake seawater, ${ }^{\mathbf{n}}$ The lower size limit in this project, ${ }^{\circ} 88 \%$ of fragments collected in this project were smaller than $10 \mathrm{~mm}$, while fragments between 5 and $10 \mathrm{~mm}$ in size account for approximately $5 \%$ of all microplastics shown in Supplementary Fig. 2. Thus, $83 \%(0.88 \times 0.95)$ was categorized as microplastics $<5 \mathrm{~mm}$ in size. ${ }^{\mathbf{p}}$ Bongo net, ${ }^{\mathbf{9}}$ Plankton net, ${ }^{\mathbf{r}}$ These data were included only in Levels 0 and 1 data because the intake depth of $11 \mathrm{~m}$ was largely different from other studies. ${ }^{\mathbf{s}}$ The proportions of fragments were given at each station (see Level_1_2.csv of Supplementary data). ${ }^{\mathbf{t}} 0.1-\mathrm{mm}$ was used for the continuous seawater intake. ${ }^{\text {" }} \mu \mathrm{FTIR}$ is used for the continuous seawater intake

'These data were included only in Levels 0 and 1 data because the intake depth of $8.5 \mathrm{~m}$ was largely different from other studies

directions. Fourth, attenuated total reflection Fourier transform infrared spectrophotometer (ATR-FTIR), $\mu$ FTIR, or Raman spectroscopy were not used to account for non-plastic materials in 10 projects conducted mostly in the early 2010s. Identification by the naked eye and/or using a stereomicroscope may have led to an overestimation of the particle counts $<2 \mathrm{~mm}$ (which accounted for $66.2 \%$ of all particles; see Supplementary Fig. 2) by approximately 50\% [5]. Meanwhile, identification using a stereomicroscope has also led to an underestimation of particle counts $<50 \mu \mathrm{m}$ with a statistical significance [36]. However, the targets of the previous studies in Table 1 were microplastics larger than several hundreds of $\mu \mathrm{m}$ in size, thus these early projects may have overestimated the particle count by approximately $30 \%(\sim 66.2 \% \times 50 \%)$. Both sizes and surface areas of microplastics show a continuous distribution [37] and, thus, the overestimation in small microplastics could be observed even if equivalent lengths computed from areas (e.g., [38]) were used for a measure of microplastic size.

The microplastic abundance metric for the Level-0 data is the particle count per unit seawater volume (pieces $\mathrm{m}^{-3}$ ). Abundance was measured directly using a flowmeter (12 projects) or intake water (4 projects). However, 11 projects measured abundance per unit area, which was computed by converting flowmeter (projects $\# 5$, \#6 and \#21) or global navigation satellite system data (projects \#1, \#4, \#7, \#9, \#14, \#15, \#16, and \#20). The seawater volume for each of these 11 projects was computed by multiplying the area by tow depth (half the height of the tow net). The abundance in Project \#6 was given by weight. For consistency, this was converted into a particle count according to the Eqs. (4) (7) shown later, although Project \#6 converted from the weight to a particle count in a statistical manner.

Level 1 - calibration by removal of fibrous microplastics Including fibrous microplastics can cause a pseudo difference in microplastic abundance estimates obtained from different projects; while one group of projects provided abundance data for microplastics including fiber, another group omitted fibrous microplastics from their estimates. Fibrous microplastics were unlikely to have been quantified precisely, unless clean-air devices were used to prevent airborne contamination during sampling or processing, or airborne contamination was removed by a blank test $[39,40]$. In addition, sampling gear, such as a tow net made from synthetic fibers, might be a source of contamination. Thus, some of the projects $(\# 2$, \#3, \#5, \#7, and \#17) excluded fibrous microplastics when creating their datasets. Meanwhile, fibrous microplastics constituted a non-negligible fraction of microplastics collected in the ocean close to the coast (projects \#13 and \#18), or in an estuary (Project \#19).

We excluded the fibrous microplastics from the original data as a data quality control to reduce the pseudo difference in synthesizing the data obtained by the various projects. In total, 21 of 27 projects provided nonfibrous microplastic proportions (Table 1); multiplying these proportions given in the Level-0 data resulted in the Level-1 data excluding fibrous microplastics (pieces $\mathrm{m}^{-3}$ ). The relatively high ratios in Table 1 suggest that fibrous microplastics were a minor component of all microplastics, particularly in the open ocean; textile fibers made from polyester or polyamide are heavier than seawater and are unlikely to move a long distance from land. Recently, Suarial et al. [41] showed that $79.5 \%$ of fibers recording in the world's ocean are cellulosic, and $12.3 \%$ are of animal origin. Therefore, the ratios were assumed to be $100 \%$ for all projects in which the ratios of non-fibrous microplastics were not recorded (projects \#1, \#4, \#11, \#20, \#22, and \#23).

\section{Level $2 p$ - processing for wind/wave correction}

The Level-1 data were standardized to obtain the total particle count, by vertically integrating microplastic abundance over the entire water column using the wind speed and significant wave heights during each 
microplastic survey ('wind/wave correction' [5, 32]). This processing step was applied because abundance data of buoyant microplastics from surface net tows vary depending on the oceanic turbulence under different ocean conditions [9, 42, 43].

The vertical distribution of the microplastic concentration $(N)$ can be approximated as follows:

$$
N=N_{0} e^{\frac{w}{A_{0}} z}
$$

where $N_{0}$ denotes the particle count per unit seawater volume around the sea surface $(\mathrm{z}=0)$, which corresponds to the Level- 1 data in the present study; $w$ is the terminal rise velocity of the microplastics $\left(5.3 \mathrm{~mm} \mathrm{~s}^{-1}\right)$, which was obtained experimentally [43]; and $z$ is the vertical axis, measured upward from the sea surface. The vertical diffusivity $A_{0}$ was calculated as:

$$
A_{0}=1.5 u_{*} k H_{s}
$$

where $u_{*}$ represents the friction velocity of water (= $\left.\sqrt{C_{d} \rho_{a} / \rho_{w}} W_{10}\right) ; k$ is the von Karman constant (0.4); Hs is significant wave height; and $W_{10}$ is wind speed at 10 $\mathrm{m}$ from the sea surface [9]. In the present study, the air density $\left(\rho_{a}\right)$, the seawater density $\left(\rho_{w}\right)$, and drag coefficient $\left(C_{d}\right)$ are set to $1.25 \mathrm{~kg} \mathrm{~m}^{-3}, 1025 \mathrm{~kg} \mathrm{~m}^{-3}$, and $1.2 \times$ $10^{-3}\left(4 \mathrm{~m} \mathrm{~s}^{-1}<W_{10}<11 \mathrm{~m} \mathrm{~s}^{-1}\right.$ in Large and Pond [44]), respectively, so that $u_{*} \approx 0.0012 W_{10}$. The daily windspeed data, provided by the Japanese Ocean Flux Data Sets with Use of Remote Sensing Observations (JOFURO [45];), were obtained from multiple satellite observations for the period 1988-2013. In addition, daily wind-speed data acquired by the Advanced Scatterometer (ASCAT) [46] from 2014 to the present were used. Daily significant wave heights were computed using the University of Miami wave model (version 1.0.1 [47];) over the world's oceans within $\pm 80^{\circ}$ latitude to reduce assumptions of wave properties (e.g., wave speed of dominant wave) included in the parameterization (e.g., [9]). However, the readers who prefer the parameterization rather than the wave model can replace the modeled wave heights given in the supplementary data (Level-012.csv) with other choices. The wave model was driven by the wind data obtained by the J-OFURO and ASCAT. These wind-speed and wave-height data, which were gridded with a $0.25^{\circ}$ horizontal resolution in latitude and longitude, were used for the Eq. (2) on the same date and at the same location as the actual observations of each project listed in Table 1.

Vertically integrating Eq. (1) from the sea surface $(z=$ $0)$ to an infinitely deep layer $(z \rightarrow-\infty)$ yields the total particle count of microplastics per unit area $(M)$ as follows:

$$
M=N_{0} A_{0} / w .
$$

The result thus obtained, in pieces $/ \mathrm{km}^{2}$, is independent of oceanic conditions. However, dependence of the terminal rise velocity $(w)$ on the total particle count $(M)$ was examined as shown later in the first subsection in Results and discussion.

\section{Level $2 \mathrm{w}$ - conversion from particle count to weight}

The Level-2p particle count was converted to weight in accordance with Isobe et al. [5]. Each microplastic fragment was assumed to be a flat cylinder with a base diameter and height of $\delta$ and $\gamma \delta$, respectively, where $\delta$ is the maximum size of the fragments, and $\gamma$ is an adjustable constant (0.4) selected through trial and error to be consistent with the microplastic weight measured directly using a mass scale [5]. We approximated the size distribution of the total particle count of microplastics as follows:

$$
v(\delta)=\beta \delta e^{-\alpha \delta},
$$

where $\alpha\left(0.83 \mathrm{~mm}^{-1}\right)$ represents the reciprocal of the mode size $(1.2 \mathrm{~mm})$ obtained by Project $\# 2$ across the Southern Ocean and western Pacific, and $\beta$ is calculated from Eq. (4) as follows:

$$
\beta=\frac{\int_{\delta_{1}}^{\delta_{2}} v d \delta}{\int_{\delta_{1}}^{\delta_{2}} \delta e^{-\alpha \delta} d \delta}=\frac{M}{\left[-\frac{1}{\alpha}\left(\frac{1}{\alpha}+\delta\right) e^{-\alpha \delta}\right]_{\delta_{1}}^{\delta_{2}}},
$$

where $M$ represents the Level-2p data for each project in Table 1 (Eq. (3)), and the operator $[f(\delta)]_{\delta_{1}}^{\delta_{2}}$ corresponds to $f\left(\delta_{2}\right)-f\left(\delta_{1}\right)$.

Then, we calculated the microplastic weight $(W)$ for particle sizes between $\delta_{1}(0.3 \mathrm{~mm})$ and $\delta_{2}(5 \mathrm{~mm})$, as follows:

$$
\begin{aligned}
W & =\int_{\delta_{1}}^{\delta_{2}} \rho \gamma \delta\left(\frac{\delta}{2}\right)^{2} \pi v d \delta \\
& =-\rho \gamma \beta \pi\left[e^{-\alpha \delta}\left(\frac{\delta^{4}}{\alpha}+\frac{4 \delta^{3}}{\alpha^{2}}+\frac{12 \delta^{2}}{\alpha^{3}}+\frac{24 \delta}{\alpha^{4}}+\frac{24}{\alpha^{5}}\right)\right]_{\delta_{1}}^{\delta_{2}},
\end{aligned}
$$

or concisely expressed as:

$$
W=-\rho \gamma \beta \pi\left[e^{-\alpha \delta} \sum_{n=1}^{5} \frac{\theta_{n} \delta^{5-n}}{\alpha^{n}}\right]_{\delta_{1}}^{\delta_{2}},
$$

where $\theta_{n}=\theta_{n-1}(6-n), \theta_{0}=0.2, \rho$ denotes the plastic density $\left(\sim 1.0 \mathrm{~g} \mathrm{~cm}^{-3}\right)$ close to polyethylene and polypropylene which are majority of plastic polymers collected in surface net tows in the ocean [48], $W$ is weight per unit area $\left(\mathrm{g} / \mathrm{km}^{2}\right)$. Based on all microplastics collected in Project \#2, Isobe et al. [5] estimated that the 
microplastic weight approximated by Eq. (7) was $85.3 \%$ of the actual weight.

For comparison, we also created an alternative weight data by using a statistical manner given by the Project \#6 as follows:

$$
\log _{10} W\left(g_{k m^{-2}}\right)=1.22 \log _{10} M\left(\text { pieces } k m^{-2}\right)-4.04,
$$

where $M$ represents the Level-2p data as in Eq. (5). The weight obtained by Eq. (8) $\left(W_{\mathrm{Eq}(8)}\right)$ is expressed approximately by $W$ in Eq. (7) as follows:

$$
\log _{10} W_{E q .(8)}=1.2 \log _{10} W_{E q \cdot(7)}-2.0 .
$$

The dataset converted using Eq. (7) is referred to as the Level-2w1, while Eq. (8) created the Level-2w2 data. The difference between the Level-2w1 and 2w2 data was described in the first subsection in Results and discussion.

\section{Level $3 p$ and $3 w$ - gridded data through OIM}

The total particle count (Level 2p) and weight (Level $2 w 1$ and $w 2)$ per unit area were interpolated to the gridded data (Level 3p, 3w1, and 3w2) using an OIM. Although OIM algorithms have been established by several research projects, the method of Daley [49] and Kako et al. [46] was adopted in the present study as follows:

$$
A_{g}=B_{g}+\sum_{i=1}^{N}\left(O_{i}-B_{i}\right) W_{i}
$$

where $A_{g}\left(B_{g}\right)$ is an analysis (first guess) value to be interpolated to a grid cell, $g, 5^{\circ} \times 2^{\circ}$ in longitude and latitude, and $O_{i}\left(B_{i}\right)$ is an observed (first guess) value given at observation point $i$, and $W_{i}$ denotes a weight function at observation point $i$; there are $N$ observation points. The optimum weight, computed so as that the errors included in observed $(O)$ and first guess $(B)$ values in Eq. (10) are unbiased and uncorrelated to generate gridded data free of biases, can be expressed as

$$
\sum_{j=1}^{N} \sum_{i=1}^{N}\left(\mu_{i j}^{B}+\mu_{i j}^{O}\right) W_{i}=\mu_{i g}^{B}
$$

where $\mu_{\mathrm{i}, j}\left(\right.$ or $\left.\mu_{i, g}\right)$ is a coefficient of error correlation between grid points $i$ and $j$ (or g); superscripts $B$ and $O$ denote observed and first guess values, respectively; $\mu_{i, j}^{O}$ is an identity matrix ( 1 only if $i=j$, otherwise 0 ); and $\mu_{i, j}^{B}$ is estimated to be

$$
\mu^{B}=e^{\left(\begin{array}{cc}
r_{m}^{2} & r_{z}^{2} \\
L_{m}^{2} & L_{z}^{2}
\end{array}\right)}
$$

where $r_{z}\left(r_{m}\right)$ denotes the zonal (meridional) distance between two arbitrary points $(i-j$, and $i-g$ in Eq. (11)), and $L_{z}\left(L_{m}\right)$ is the decorrelation scale in the zonal (meridional) direction $[46,50]$. In the present study, the decorrelation scales of 1000 and $500 \mathrm{~km}$ were chosen for $L_{z}$ and $L_{m}$, respectively, through trial and error. Interpolation was not conducted at grid cells having fewer than observed data points within the decorrelation scales. Zero was used as the first-guess value over the entire domain.

\section{Level $3 \mathrm{pm}$ and $3 \mathrm{wm}$ - gridded monthly surface concentration data}

The total particle count (Level 3p) and weight (Level $3 \mathrm{w})$ of microplastics in the grid cells are available for computing the concentration $\left(N_{0}\right.$ in Eq. (3)) under the various wind/wave conditions. For instance, the Levels $3 p$ and $3 w 1$ data were converted to the surface concentration for each month, under the average wind speed and wave height for the period 1993-2018. To be sure, the seasonal variation of surface microplastic abundance should be validated by field surveys in the actual ocean, and so this is a subject of future research beyond the present study. Nonetheless, these data should allow for accurate laboratory-based studies on impact to aquatic organisms exposed to microplastics, so that microplastic concentrations used for exposures are comparable with those in reality. In addition, these data may be capable of predetermining appropriate months and locations of a field campaign to collect sufficiently large numbers of microplastics. The wind speed and wave height data used to create the Level-2 dataset were averaged monthly for the period 1993-2018. Using Eqs. (2) and (3), we converted abundance at Level $3 \mathrm{p}$ and $3 \mathrm{w} 1$ ( $M$ in the equations) to the Level-3 pm and -3wm surface concentrations, respectively, for each month using the monthly averaged wind speed and wave height. Other parameters, such as terminal rise velocity, were the same as those in creating the Level-2 dataset.

\section{Results and discussion}

Sensitivity of parameter choices on microplastic abundance

Because of limited available knowledge regarding microplastics in the ocean, the present study had to make some parameter choices for processing the data at each level. Here we demonstrate how microplastic abundance depends on the choices made by using different parameters such as terminal rise velocities (w) in Eq. (3) and formulae to convert from the total particle count to weight.

The early plastic projects ca. 2010s may have overestimated the particle count by approximately $30 \%$ because of misidentification of small fragments in the absence of spectrometry. To quantify how the overestimation diminished the quality of the dataset, the Level-2p data were created from the Level-1 so that the particle counts were reduced by $30 \%$ in the projects without spectrometry (Table 1). It was found that the total particle count 

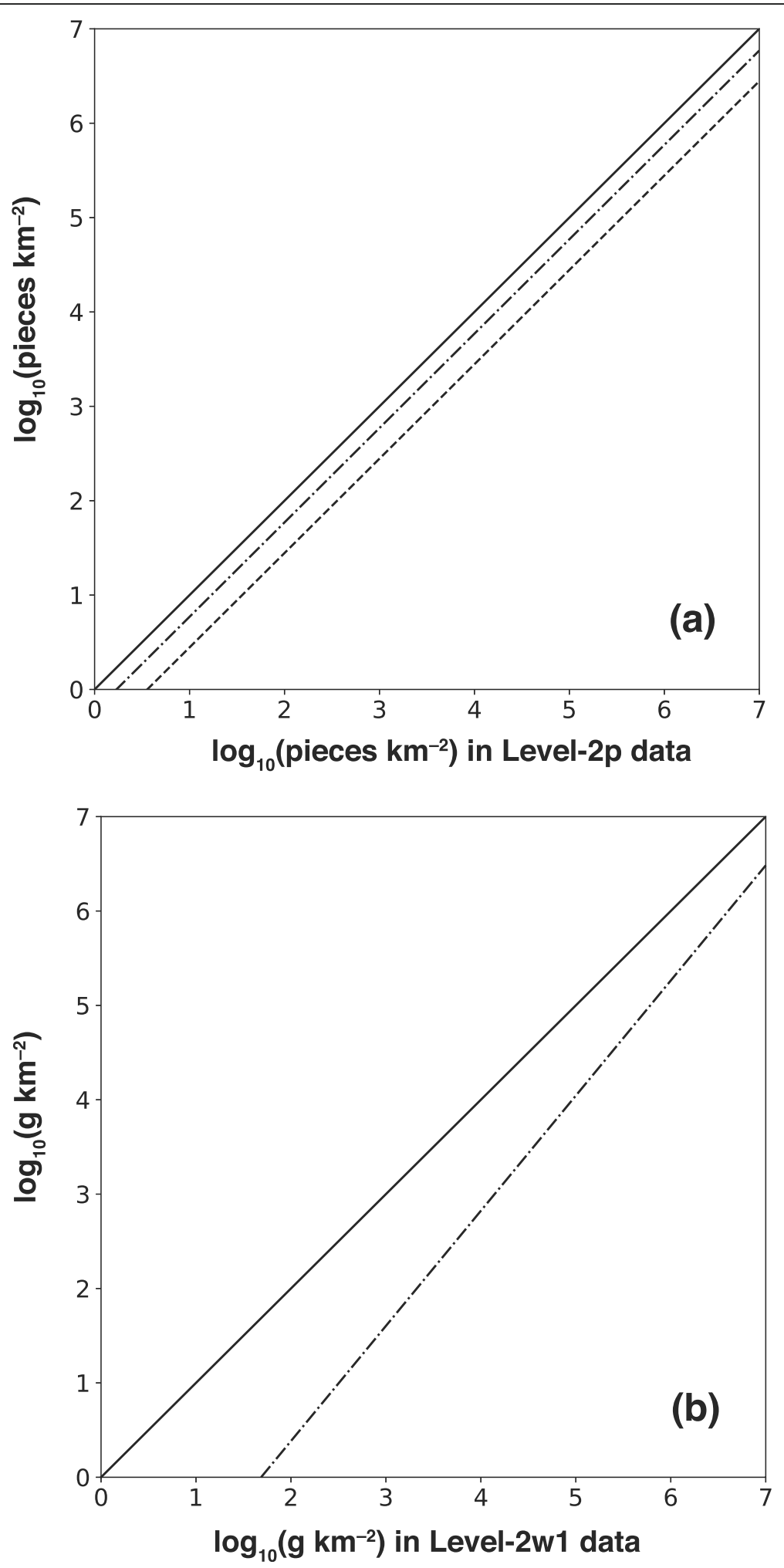

Fig. 1 Sensitivity of parameters on the deduced microplastic abundance. (a) The relationship between the Level $2 p$ data (solid line) and the same data but for the terminal rise velocity of $0.009 \mathrm{~m} \mathrm{~s}^{-1}$ (dash-dot-dash line) and $0.019 \mathrm{~m} \mathrm{~s}^{-1}$ (dashed line). (b) The relationship between the Level2w1 data (solid line) and 2w2 data (dash-dotted line) 
averaged over the world's ocean in the Level-2p data was reduced approximately by $7 \%$.

Replacing the terminal rise velocity of (Reisser et al. [43]; $w=0.0053 \mathrm{~m} \mathrm{~s}^{-1}$ ) with those experimentally estimated by Kooi et al. [42] and Poulain et al. [38] decreased the total particle count $(M)$. Kooi et al. [42] estimated $0.009 \mathrm{~m} \mathrm{~s}^{-1}$ and $0.019 \mathrm{~m} \mathrm{~s}^{-1}$ for microplastics with sizes of $0.5 \sim 1.5 \mathrm{~mm}$ and $1.5 \sim 5 \mathrm{~mm}$, respectively, while the experimental velocities for microplastics with sizes of $1 \sim 5 \mathrm{~mm}$ in [38]; their Fig. 1B) had nearly the same magnitude as those in Kooi et al. [42]. When $w$ in Eq. (3) was replaced with $0.009 \mathrm{~m} \mathrm{~s}^{-1}$, the total particle count $\left(M_{0.009}\right)$ was simply converted to $M_{0.009}=(0.0053 / 0.009) \quad M=0.59 M$, where $M$ represents Level-2p data (Fig. 1a). Likewise, $M_{0.019}=0.28 M$ (Fig. 1a).

The weight of microplastics ( $W$ in Eq. (7)) depends significantly on the choice of the formula to convert from the total particle count to weight. When the statistical manner of Eq.
(8) was adopted for the conversion, the weight in Level-2w1 data decreased to $2 \sim 20 \%$ in the range of $10^{2} \sim 10^{7} \mathrm{~g} \mathrm{~km}^{-2}$ (Eq. (9); Fig. 1b). This is probably because the particle counts in smaller microplastic sizes from Project \#6 (their Fig. 3) were more abundant than those observed in Project \#2 (Supplementary Fig. 2). The size distributions are unlikely to be homogeneous in the world's ocean and, therefore, it should be noted that the current estimate of weight includes uncertainty as shown in Fig. 1b. Therefore, for reference, the present study created Level-2w2 data using Eq. (8) in addition to Level-2w1 data. Likewise, the gridded data through the OIM using Level-2w2 data were created as Level-3w2 data.

\section{D maps and statistics}

The present study's objective was to generate a new, publicly available dataset and facilitate microplastic
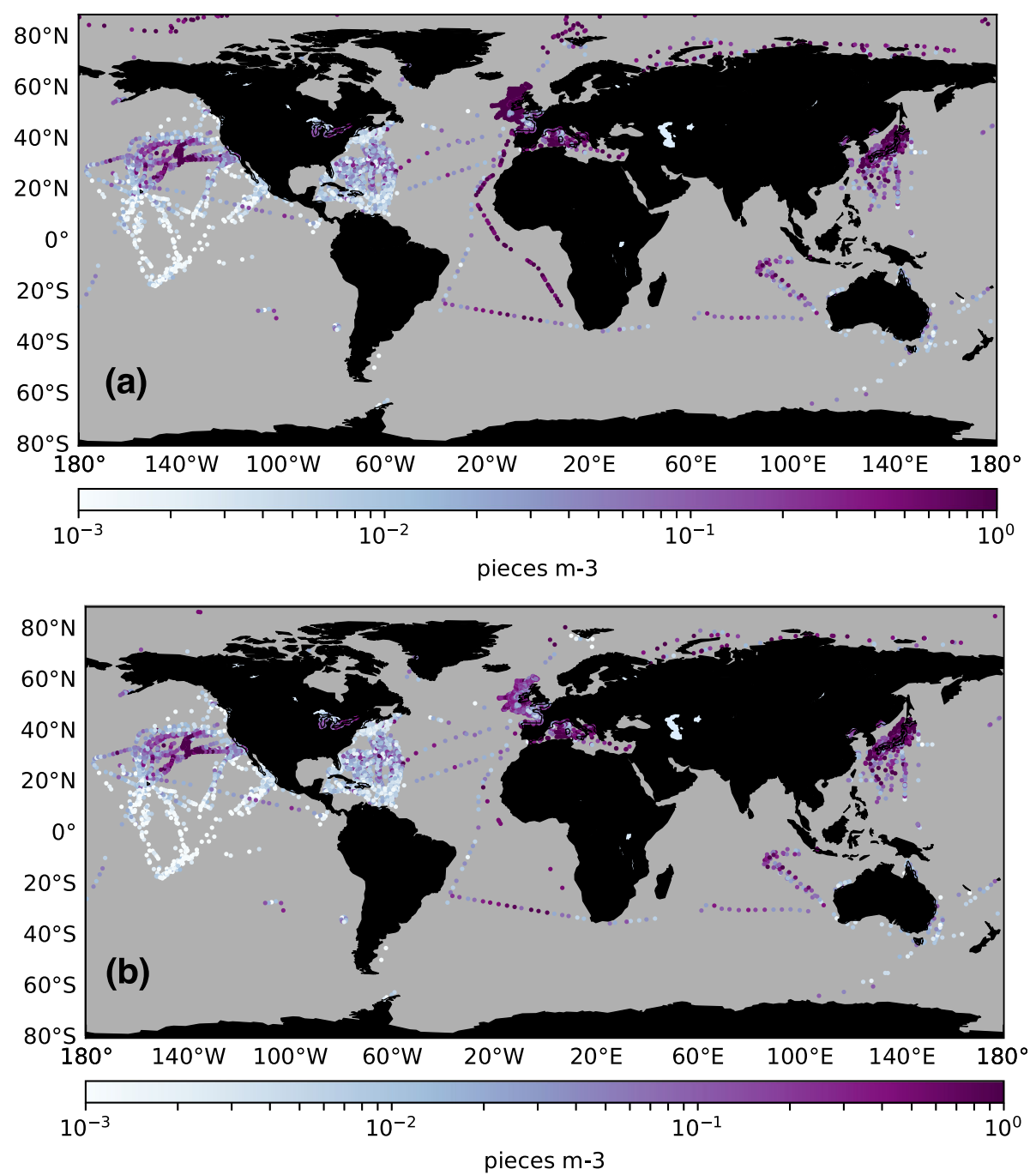

Fig. 2 Microplastic abundance at (a) Level 0 and (b) Level 1. Abundance is represented by the colors in the scales shown at the bottom of each panel 
research based on actual and reliable ocean data. Although further and more detailed interpretations, analyses, and processing are expected to be carried out by researchers who download the dataset, we present twodimensional (2D) maps with brief explanations of the features of the dataset.

Figure $2 \mathrm{a}$ and $\mathrm{b}$ provide $2 \mathrm{D}$ maps of the Level-0 and Level-1 data, respectively, including the microplastic abundance obtained by Project \#21, conducted in the Great Lakes of the United States. Microplastic surveys have been conducted in the seas around the United States, European countries, such as the Mediterranean Sea and the eastern North Atlantic, and Japan. Approximately $46 \%$ of microplastic surveys have been conducted in the mid-latitude ocean between $30^{\circ} \mathrm{N}$ and $60^{\circ} \mathrm{N}$, while low-latitude surveys of the Indian Ocean and western Pacific (between $30^{\circ} \mathrm{S}$ and $30^{\circ} \mathrm{N}$, and $40^{\circ} \mathrm{E}$ and $180^{\circ} \mathrm{E}$, respectively) account for only $5 \%$ of all data.

Integrating the microplastic abundance over the entire water column yielded 2D maps of the total particle count (Level 2p; Fig. 3a) and weight (Level 2w1; Fig. 3b), after removing effects of winds/waves during the observations. Note that the Great Lakes and 2019 data were excluded because of a lack of wind/wave data among the satellite data. Nonetheless, 679 survey positions were added to Fig. 2, because Project \#9 originally provided vertically-integrated microplastic abundance data after the wind/wave correction, and those data are not included among the Levels- 0 and -1 data.

The gridded data created by the OIM were displayed in 2D maps of the total particle count (Level 3p; Fig. 4a) and weight (Level 3w1; Fig. 4b), which covered
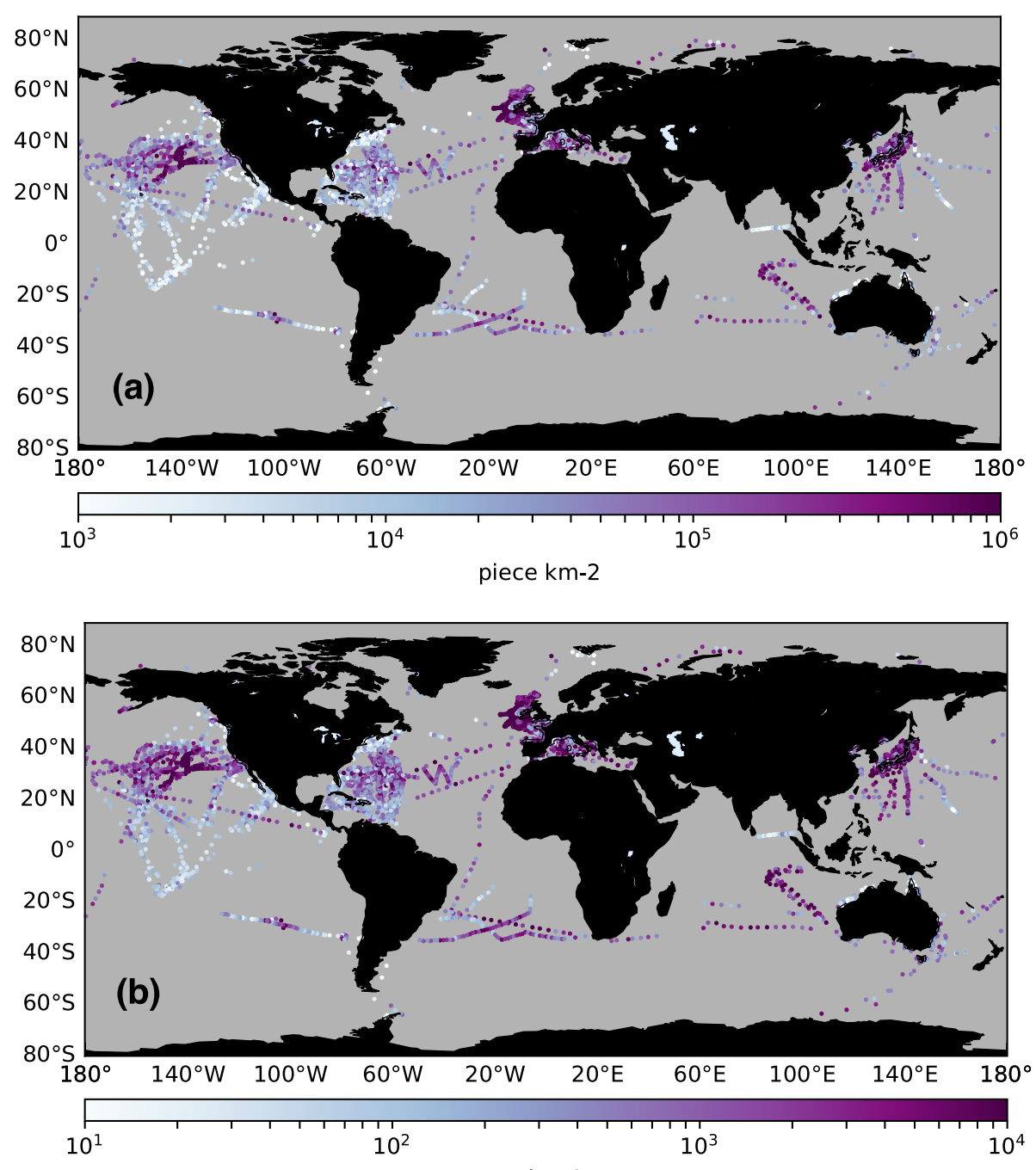

$\mathrm{g} \mathrm{km-2}$

Fig. 3 Same as Fig. 2, but for (a) Level 2p and (b) Level 2w1 

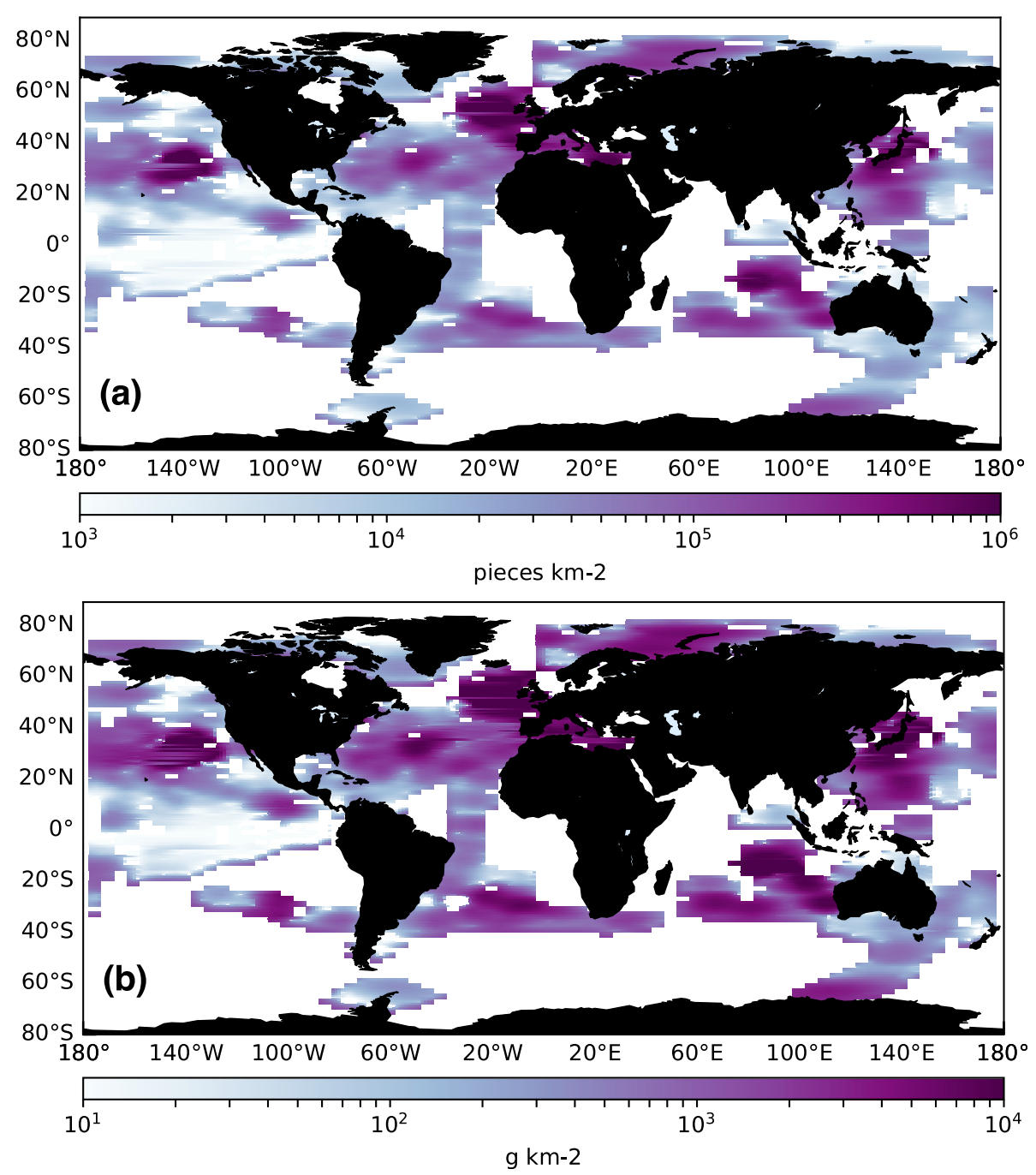

Fig. 4 Same as Fig. 2, but for (a) Level 3p and (b) Level 3w1

approximately $60 \%$ of the entire ocean. Note that the grid cells remain white in Fig. 4 when there were fewer than two observed data points within the decorrelation scales. In addition to the interior of the midlatitude subtropical gyres, including the so-called 'Great Garbage Patch' (e.g., [51]) areas, a large number of pelagic microplastics were detected in the seas around Europe, the East Asian seas, and the eastern Indian
Ocean. The sum of the particle count (weight) of microplastics was estimated at 24.4 trillion pieces $\left(8.2 \times 10^{4} \sim 57.8 \times 10^{4}\right.$ tons) (Table 2$)$, which was larger than the conservative estimate of Eriksen et al. [7]; 5 trillion pieces, and $25 \times 10^{4}$ tons especially for the particle count. However, the present estimates are also conservative because gridded data were mostly absent for the western Indian Ocean and South China

Table 2 Microplastic abundance: Level-3p and -3w data (Fig. 4). These values were obtained from grid cells where more than two values exited (i.e., all grid cells except the white areas). Total abundance was computed so that values were representative of each $5^{\circ}$-longitude $\times 2^{\circ}$-latitude grid cell. The particle count (weight) per unit area was rounded to the $1000(10)$

\begin{tabular}{lll}
\hline & Total particle count & Weight (3w2 3w1) \\
\hline Average & 113,000 pieces $\mathrm{km}^{-2}$ & $130 \sim 2670 \mathrm{~g} \mathrm{~km}^{-2}$ \\
Maximum $\left(2.5^{\circ} \mathrm{E}, 53.0^{\circ} \mathrm{N}\right)$ & $5,300,000$ pieces km & $14,580 \sim 126,000 \mathrm{~g} \mathrm{~km}{ }^{-2}$ \\
Total abundance & $2.44 \times 10^{13}(24.4$ trillion) pieces & $(8.2 \sim 57.8) \times 10^{4}$ tons \\
\hline
\end{tabular}


Sea, where the South Asia, Southeast Asia, and China generate approximately $68 \%$ of all mismanaged plastic waste worldwide [52].

The surface concentrations, represented by the particle count (weight) per unit seawater volume are shown in Fig. 5a and b (Fig. 5c and d) for February and August, respectively, as exemplified by the monthly data. The particle count and weight increased in the Northern Hemisphere during the boreal summer under calm oceanic conditions. At the same time, the seasonality of microplastic abundance was not remarkable in the Southern Hemisphere, probably due to the relatively small amount of pelagic microplastics. The annuallyaveraged abundance (both particle count and weight) and maximum values over the entire domain are listed in Table 3.

\section{Conclusion -recommendations for future surveys}

Microplastics are oceanic pollutants that have yet to be archived sufficiently for mapping climatological state or variability over the world's oceans, despite observations dating back to the 1970s [53]. The present study attempted to create state-of-the-art 2D maps of microplastic abundance, based on published and unpublished data. However, protocols for microplastic field surveys have only recently become available (e.g., $[2,3]$ ), so the sharing and synthesis of observed data, which could facilitate ocean plastic studies, has only just begun. The field campaigns that must be prioritized to further advance marine-plastic-pollution research are discussed below.

First, locations where large amounts of mismanaged plastic waste are discharged should be intensively studied. In particular, a notable shortcoming of the present dataset is the lack of microplastic data for the Indian Ocean and the seas around Southeast Asia (including the South China Sea). Besides waters close to land masses, surveys in the subtropical convergence zones approximately across the $30^{\circ}$-latitude in both hemispheres should be prioritized to determine the total amount of plastics in the world's oceans.

Second, microplastic abundance in the subsurface layer of the ocean should be explored. Recent observations of pelagic microplastics have revealed that a non-negligible fraction of microplastics exists in the subsurface layers of coastal waters [36], and in intermediate and abyssal layers of the open ocean [30, 54, 55]. It has been suggested that biofouling [56], inclusion within marine aggregates [57-60], and inclusion within fecal pellets [61] allow microplastics lighter than seawater to settle in the abyssal ocean. Thus, microplastic abundance in the ocean is likely to be much greater than estimated. Three-dimensional maps of microplastic abundance, rather than the 2D maps presented here, are required to determine the ultimate fate of marine plastic debris.
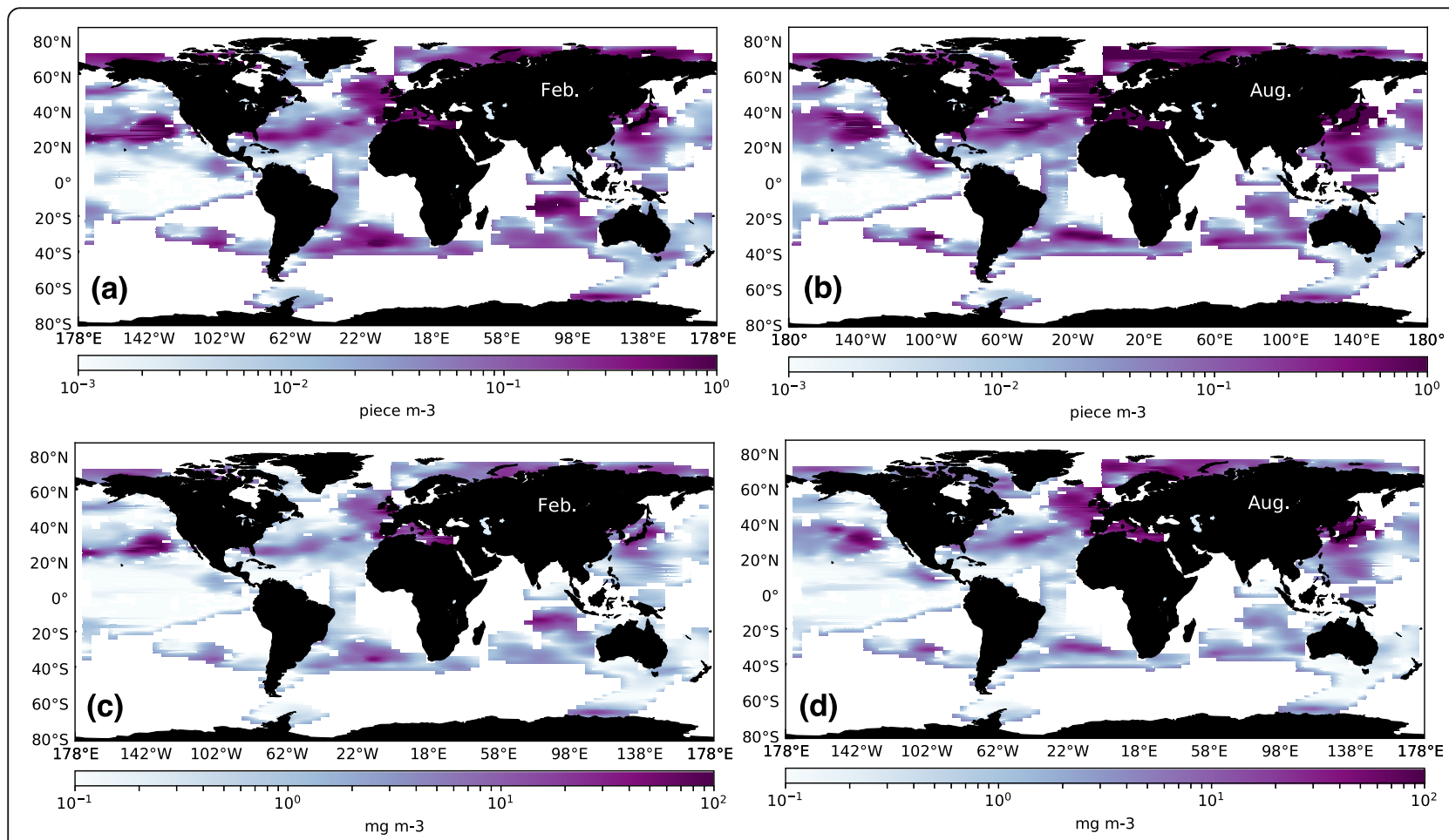

Fig. 5 Same as Fig. 2, but for (a) Level 3 pm in February, (b) Level 3 pm in August, (c) Level 3wm in February, and (d) Level 3wm in August 
Table 3 Microplastic abundance: Level-3 pm and -3wm data (Fig. 5). The average, standard deviation, and maximum values in the table were computed based on the abundance values for all months

\begin{tabular}{lll}
\hline & Particle count (pieces $\left.\mathbf{~ m}^{\mathbf{- 3}}\right)$ & Weight $^{\left(\mathbf{m g ~ m}^{\mathbf{3}}\right)}$ \\
\hline Average & 0.3 & 7.8 \\
Maximum $\left(2.5^{\circ} \mathrm{E}, 53.0^{\circ} \mathrm{N}\right.$, May) & 59.4 & 1405.3 \\
\hline
\end{tabular}

Third, field survey protocols of very small microplastics $(<300 \mu \mathrm{m})$ urgently required further development and optimization. The lower size limit of ocean microplastics investigated to date is dependent on both the mesh size of tow nets used in field surveys and the operational limitations of the equipment, such as FTIR. However, some studies have reported the existence of very small microplastics down to several tens of $\mu \mathrm{m}$ in the open ocean $[38,55,62]$ and coastal waters [36]. Moreover, the drifting of nanoplastics $(<1 \mu \mathrm{m})$ in the ocean was suggested [63]. It is plausible that very small microplastics and nanoplastics could exist in the marine environment, if degradation and fragmentation proceed continuously in nature. Besides these very small microplastics, Tokai et al. [37] reported that $60 \%$ of microplastic particles with the size between $0.4 \mathrm{~mm}$ and $1 \mathrm{~mm}$ pass through the $0.333-\mathrm{mm}$ mesh of surface sampling nets. The fate of plastic debris will remain obscure unless these missing plastic particles are quantified in the water column and bottom sediments.

\section{Supplementary Information}

The online version contains supplementary material available at https://doi. org/10.1186/s43591-021-00013-z.

\section{Additional file 1: Supplementary Fig. 1 Number of microplastic} surveys conducted (see also Table 1). The upper panel shows the number in each year from 2000 to 2019, while the lower panel represents the number during each month for the same period.

Additional file 2: Supplementary Fig. 2 Size distribution of microplastics collected by Project \#2. Bar height represents the particle count per unit seawater volume. Note that the bar width is $0.1,1$, and 10 $\mathrm{mm}$ for microplastics $<5,5-10$, and $10-50 \mathrm{~mm}$, respectively. The dots indicate cumulative ratios computed for microplastics of $50 \mathrm{~mm}$ downward. Plastic fragments > 5 (2) $\mathrm{mm}$ in size account for $6.3 \%$ (33.8\%) of all fragments.

Additional file 3: All data generated are available in supplementary information files (Level012.csv, Level3.csv, Level3pm.cSV, and Level3wm.csv).

\section{Acknowledgements}

This work was supported by Ministry of the Environment, Japan. The IDEA Consultants Inc. helped collect microplastic data observed by the researchers.

\section{Authors' contributions}

All authors contributed to microplastic sampling in their field surveys, and created the Level-0 data. SK and SI contributed to generate wind/wave data. Al and SK created Level-1, 2, and 3 data, and contributed to write the manuscript. All authors read and approved the final manuscript.

\section{Funding}

Al was supported by the Environmental Research and Technology Development Fund (JPMEERF18S20201) of the Ministry of the Environment, Japan, and by SATREPS of Japan International Cooperation Agency and Japan Science and Technology Agency. Data from IFREMER was collected within the MSFD and supported by the French ministry of Environment.

\section{Availability of data and materials}

All data generated are available in supplementary information files (Level012.csv, Level3.csv, Level3pm.csv, and Level3wm.csv).

\section{Declarations}

Competing interests

The authors declare that they have no competing interests.

\section{Author details}

${ }^{1}$ Research Institute for Applied Mechanics, Kyushu University, 6-1 Kasuga-Koen, Kasuga 816-8580, Japan. ${ }^{2}$ Training Vessel Kagoshima maru, Faculty of Fisheries, Kagoshima University, 4-50-20 Shimoarata, Kagoshima 890-0056, Japan. ${ }^{3}$ Research Center for Oceanography, Indonesian Institute of Sciences, Jl. Pasir Putih 1, Ancol Timur, Jakarta 14430, Indonesia. ${ }^{4}$ Departamento de Biología, University of Cadiz and European University of the Seas (SEA-EU), Instituto Universitario de Investigación Marina (INMAR), E-11510 Puerto Real, Spain. ${ }^{5}$ IFREMER, Laboratoire LER/PAC, immeuble Agostini ZI Furiani, 20600 Bastia, France. ${ }^{6}$ Training and research Vessel Umitaka maru, Tokyo University of Marine Science and Technology, 4-5-7 Konan, Minato-ku, Tokyo 108-8477, Japan. ${ }^{7}$ Department of Life Sciences, The University of the West Indies, St. Augustine Campus, W.I, Trinidad and Tobago. ${ }^{8}$ School of Fisheries Sciences, Hokkaido University, 3-1-1, Minato-cho, Hakodate, Hokkaido 041-8611, Japan. ${ }^{9} \mathrm{Civil}$ Engineering Research Institute for Cold Region, 1-3-1-34 Toyohira, Sapporo 062-8602, Japan. ${ }^{10}$ Department of Engineering, Ocean Civil Engineering Program, Kagoshima University, Kagoshima 890-0054, Japan. ${ }^{11}$ Pacific Geographical Institute, Far Eastern Branch of Russian Academy of Sciences, Radio 7, 690041 Vladivostok, Russia.

${ }^{12}$ Norwegian Institute for Water Research, Gaustadalléen 21, Oslo, Norway.

${ }^{13}$ Department of Biological Sciences, University of Bergen, Postboks 7803, 5020 Bergen, Norway. ${ }^{14}$ Pennsylvania State University, The Behrend College, 4701 College Dr, Erie, PA 16563, USA. ${ }^{15}$ Atmosphere and Ocean Research Institute, The University of Tokyo, 5-1-5 Kashiwanoha, Kashiwa 277-8564, Japan. ${ }^{16}$ Faculty of Fisheries, T/S Nagasaki-Maru, Nagasaki University, 1-14 Bunkyo machi, Nagasaki city, Nagasaki 852-8521, Japan. ${ }^{17}$ Faculty of Fisheries Sciences, Hokkaido University, 3-1-1, Minato-cho, Hakodate, Hokkaido 041-8611, Japan. ${ }^{18}$ Institute of Integrated Science and Technology, Nagasaki University, 1-14 Bunkyo machi, Nagasaki city, Nagasaki 852-8521, Japan.

${ }^{19}$ Tokyo University of Marine Science and Technology, 4-5-7 Konan, Minato-ku, Tokyo 108-8477, Japan. ${ }^{20}$ National Marine Environmental Monitoring Center, Linghe Street 42, Dalian 116023, China.

Received: 2 March 2021 Accepted: 16 July 2021

Published online: 09 September 2021

\section{References}

1. Cowger W, Booth AM, Hamilton BM, Thaysen C, Primpke S, Munno K, et al. Reporting Guidelines to increase the reproductivity and comparability of research on microplastics. Appl Spectrosc. 2020;74:1066-77.

2. GESAMP. Guidelines or the monitoring and assessment of plastic litter and microplastics in the ocean. In: Kershaw PJ, Turra A, Galgani F, editors. (IMO/ FAO/UNESCO-IOC/UNIDO/WMO/IAEA/UN/UNEP/UNDP/ISA Joint Group of Experts on the Scientific Aspects of Marine Environmental Protection). Rep. Stud. GESAMP No. 99; 2019. 
3. Michida Y, Chavanich S, Cózar CA, Hagmann P, Hinata H, Isobe A, et al. Guidelines for harmonizing ocean surface microplastic monitoring methods. Ministry Environ Japan. 2020; https://www.env.go.jp/en/water/marine_litter/ guidelines/guidelines.pdf. Accessed 23 February 2021.

4. Burton GA Jr. Stressor exposures determine risk: so, why do fellow scientists continue to focus on superficial microplastics risk? Environ Sci Technol. 2017;51 (23):13515-6. https://doi.org/10.1021/acs.est.7b05463.

5. Isobe A, Iwasaki S, Uchida K, Tokai T. Abundance of non-conservative microplastics in the upper ocean from 1957 to 2066. Nat. Comm. 2019;10:417.

6. van Sebille E, Wilcox C, Lebreton L, Maximenko NA, Hardesty BD, Franeker JA, et al. A global inventory of small floating plastic debris. Environ Res Lett. 2015;10(12):124006. https://doi.org/10.1088/1748-9326/10/12/124006.

7. Eriksen M, Lebreton LCM, Carson HS, Thiel M, Moore CJ, Borerro JC, et al. Plastic pollution in the world's oceans: more than 5 trillion plastic pieces weighing over 250,000 tons afloat at sea. PLoS One. 2014;9(12):e111913. https://doi.org/10.1371/journal.pone.0111913.

8. Andrady AL. Microplastics in the marine environment. Mar Pollut Bull. 2011; 62(8):1596-605. https://doi.org/10.1016/j.marpolbul.2011.05.030.

9. Kukulka T, Proskurowski G, Moret-Ferguson S, Meyer DW, Law KL. The effect of wind mixing on the vertical distribution of buoyant plastic debris. Geophys Res Lett. 2012;39:L07601.

10. Cózar A, Echevarría F, González-Gordillo Il, Irigoien X, Úbeda B, HernándezLeón S, et al. Plastic debris in the open ocean. Proc Natl Acad Sci. 2014; 111(28):10239-44. https://doi.org/10.1073/pnas.1314705111.

11. Law KL, Morét-Ferguson SK, Goodwin DS, Zettler ER, DeForce E, Kukulka T, et al. Distribution of surface plastic debris in the eastern Pacific Ocean from an 11-year data set. Environ Sci Technol. 2014;48(9):4732-8. https://doi.org/1 $0.1021 / \mathrm{es} 4053076$

12. Collignon A, Hecq J-H, Galgani F, Collard F, Goffart A. Annual variation in neustonic micro- and meso-plastic particles and zooplankton in the bay of Calvi (Mediterranean-Corsica). Mar Pollut Bull. 2014;79(1-2):293-8. https:// doi.org/10.1016/.marpolbul.2013.11.023.

13. Cózar A, Sanz-Martín M, Martí E, González-Gordillo Jl, Ubeda B, Gálvez JÁ, et al. Plastic accumulation in the Mediterranean Sea. PLoS One. 2015;10(4): e0121762. https://doi.org/10.1371/journal.pone.0121762.

14. Cózar A, Martí E, Duarte CM, García-de-Lomas J, van Sebille E, Ballatore TJ, et al. The Arctic Ocean as a dead end for floating plastics in the North Atlantic branch of the Thermohaline Circulation. Sci Adv. 2017;3:e1600582.

15. Doyle MJ, Watson W, Bowlin NM, Sheavly SB. Plastic particles in coastal pelagic ecosystems of the Northeast Pacific Ocean. Mar Environ Res. 2011; 71(1):41-52. https://doi.org/10.1016/j.marenvres.2010.10.001.

16. Goldstein MC, Rosenberg M, Cheng L. Increased oceanic microplastic debris enhances oviposition in an endemic pelagic insect. Biol Lett. 2012;8(5):81720. https://doi.org/10.1098/rsbl.2012.0298.

17. de Lucia GA, Caliani I, Marra S, Camedda A, Coppa S, Alcaro L, et al. Amount and distribution of neustonic micro-plastic off the western Sandian coast (Central-Western Mediterranean Sea). Mar Environ Res. 2014;100:10-6. https://doi.org/10.1016/j.marenvres.2014.03.017.

18. Lusher AL, Tirell V, O'Connor I, Officer R. Microplastics in Arctic polar waters: the first reported values of particles in surface and sub-surface samples. Sci Rep. 2015;5(1):14947. https://doi.org/10.1038/srep14947.

19. Lusher AL, Burke A, O'Connor I, Officer R. Microplastic pollution in the Northeast Atlantic Ocean: validated and opportunistic sampling. Mar Pollut Bull. 2014;88(1-2):325-33. https://doi.org/10.1016/j.marpolbul.2014.08.023.

20. Pan Z, Guo H, Chen H. Wang S, Sun X, Zou Q et al. Microplastics in the northwestern Pacific: abundance, distribution, and characteristics. Sci Total Environ. 2019;650:1913-22. https://doi.org/10.1016/j.scitotenv.2018.09.244.

21. Pedrotti M, Petit S, Elineau A, Bruzaud S, Crebassa J-C, Dumontet B, et al. Changes in the floating plastic pollution of the Mediterranean Sea in relation to the distance to land. PLoS One. 2016;11(8)::0161581. https://doi. org/10.1371/journal.pone.0161581.

22. Reisser J, Shaw J, Wilcox C, Hardesty BD, Proietti M, Thums M, et al. Marine plastic pollution in waters around Australia: characteristics, concentrations, and pathways. PLoS One. 2013;8(11):e80466. https://doi.org/10.1371/journal. pone.0080466

23. Suaria, G., C. G, Mineo A, Lattin GL, Magaldi MG, Belmonte G, Moore CJ, et al. The Mediterranean Plastic Soup: synthetic polymers in Mediterranean surface waters. Sci Rep. 2016;6:37551.

24. Zhang W, Zhang S, Wang J, Wang Y, Mu J, Wang P, et al. Microplastic pollution in the surface waters of the Bohai Sea, China. Environ Pollut. 2017; 231(Pt 1):541-8. https://doi.org/10.1016/j.envpol.2017.08.058.
25. Zhao S, Zhu L, Wang T, Li D. Suspended microplastics in the surface water of the Yangtze estuary system, China: first observations on occurrence, distribution. Mar Pollut Bull. 2014;86(1-2):562-8. https://doi.org/10.1016/j.ma rpolbul.2014.06.032.

26. Law KL, Morét-Ferguson S, Maximenko NA, Proskurowski G, Peacock EE, Hafner J, et al. Plastic accumulation in the North Atlantic subtropical gyre. Science. 2010;329(5996):1185-8. https://doi.org/10.1126/science.1192321.

27. Mason SA, Daily J, Aleid G, Ricotta R, Smith M, Donnelly K, et al. High levels of pelagic plastic pollution within the surface waters of lakes Erie and Ontario. J Gt Lakes Res. 2020;46(2):277-88. https://doi.org/10.1016/j.jglr.201 9.12.012.

28. Kanhai LDK, Officer R, Lyashevska O, Thompson RC, O'Connor I. Microplastic abundance, distribution and composition along a latitudinal gradient in the Atlantic Ocean. Mar Pollut Bull. 2017;115(1-2):307-14. https://doi.org/10.101 6/j.marpolbul.2016.12.025.

29. Yakushev E, Gebruk A, Osadchiev A, Pakhomova S, Lusher A, Berezina A, et al. Microplastics distribution in the Eurasian Arctic is affected by Atlantic waters and Siberian rivers. Comm Earth Environ. 2021;2(1):23. https://doi. org/10.1038/s43247-021-00091-0.

30. Kanhai LDK, Gårdfeldt K, Lyashevska O, Hassellöv M, Thompson RC, O'Connor I. Microplastics in sub-surface waters of the Arctic Central Basin. Mar Pollut Bull. 2018;130:8-18. https://doi.org/10.1016/j.marpolbul.2018.03. 011.

31. Isobe A, Uchiyama-Matsumoto K, Uchida K, Tokai T. Microplastics in the Southern Ocean. Mar Pollut Bul. 2017;114(1):623-6. https://doi.org/10.1016/j. marpolbul.2016.09.037.

32. Isobe A, Uchida K, Tokai T, Iwasaki S. East Asian seas: a hot spot of pelagic microplastics. Mar Pollut Bull. 2015;101(2):618-23. https://doi.org/10.1016/j. marpolbul.2015.10.042

33. Amelineau F, Bonnet D, Heitz O, Mortreux V, Harding AMA, Karnovsky N, et al. Microplastic pollution in the Greenland Sea: background levels and selective contamination of planktivorous diving seabirds. Environ Pollut. 2016;219:1131-9. https://doi.org/10.1016/j.envpol.2016.09.017.

34. Beer S, Garmb A, Huwer B, Dierking J, Nielsen TG. No increase in marine microplastic concentration over the last three decades - a case study from the Baltic Sea. Sci Total Environ. 2018:621:1272-9. https://doi.org/10.1016/j. scitotenv.2017.10.101.

35. Galgani F, Brien AS, Weis J, loakeimidis C, Schuyler Q, Makarenko I, et al. Are litter, plastic and microplastic quantities increasing in the ocean? Microplastics Nanoplastics. 2021;1:2

36. Song YK, Hong SH, Jang M, Han GM, Rani M, Lee J, et al. A Comparison of microscopic and spectroscopic identification methods for analysis of microplastics in environmental samples. Mar Pollut Bull. 2015;93:202-9.

37. Tokai T, Uchida K, Kuroda M, Isobe A. Mesh selectivity of neuston nets for microplastics. Mar Pollut Bull. 2021;165:112111.

38. Poulain M, Mercier MJ, Brach L, Martignac M, Routaboul C, Perez E, et al. Small microplastics as a Main contributor to plastic mass balance in the North Atlantic subtropical gyre. Environ Sci Technol. 2019;53(3):1157-64 https://doi.org/10.1021/acs.est.8b05458.

39. Wesch C, Elert AM, Wörner M, Braun U, Klein R, Paulus M. Assuring quality in microplastic monitoring: about the value of clean-air devices as essentials for verified data. Sci Rep. 2017;7(1):5424. https://doi.org/10.1038/s41598-01705838-4.

40. Willis KA, Eriksen R, Wilcox C, Hardesty BD. Microplastic Distribution at Different Sediment Depths in an Urban Estuary. Front Marine Sci. 2017;4: 419.

41. Suarial G, Achtypi A, Perold V, Lee JR, Pierucci A, Bornman TG, et al. Microfibers in oceanic surface waters: A global characterization. Sci Adv. 2020;6:eaay8493.

42. Kooi M, Reisser J, Slat B, Ferrari FF, Schmid MS, Cunsolo S, et al. The effect of particle properties on the depth profile of buoyant plastics in the ocean. Sci Rep. 2016;6(1):33882. https://doi.org/10.1038/srep33882.

43. Reisser J, Slat B, Noble K, du Plessis K, Epp M, Proietti M, et al. The vertical distribution of buoyant plastics at sea: an observational study in the North Atlantic gyre. Biogeosciences. 2015;12(4):1249-56. https://doi.org/10.5194/ bg-12-1249-2015.

44. Large WG, Pond S. Open Ocean momentum flux measurements in moderate to strong winds. J Phys Oceanogr. 1981;11(3):324-36. https://doi. org/10.1175/1520-0485(1981)011<0324:OOMFMI>2.0.CO;2.

45. Tomita H, Hihara T, Kako S, Kubota M, Kutsuwada K. An introduction to JOFURO3, a third-generation Japanese ocean flux data set using remote- 
sensing observations. J Oceanogr. 2019;75(2):171-94. https://doi.org/10.1 007/s10872-018-0493-X.

46. Kako S, Isobe A, Kubota M. High-resolution ASCAT wind vector data set gridded by applying an optimum interpolation method to the global ocean. J Geophys Res Atmospheres. 2011;116:D23107.

47. Donelan MA, Curcic M, Chen SS, Magnusson AF. Modeling waves and wind stress. J Geophys Res. 2012;117:C00J23.

48. Shim WJ, Hong SH, Eo S. Marine microplastics: abundance, distribution, and composition. In: Zhen EY, editor. Microplastic contamination in aquatic environments. An emerging matter of environment urgency. Amsterdam: Elsevier; 2018. p. 409

49. Daley R. Atmospheric data analysis: Cambridge University Press; 1991.

50. Kuragano T, Shibata A. Sea surface dynamics height of the Pacific Ocean derived from TOPEX/POSEIDON altimeter data, calculation method and accuracy. J Oceanogr. 1997:53:583-99.

51. Maximenko N, Hafner J, Niiler P. Pathways of marine debris derived from trajectories of Lagrangian drifters. Mar Pollut Bull. 2012;65(1-3):51-62. https:// doi.org/10.1016/j.marpolbul.2011.04.016

52. Jambeck JR, Geyer R, Wilcox C, Siegler TR, Perryman M, Andrady A, et al. Plastic waste inputs from land into the ocean. Science. 2015;347(6223):76871. https://doi.org/10.1126/science.1260352.

53. Carpenter EJ, Smith KL J. Plastics on the Sargasso Sea surface. Science. 1972;175(4027):1240-1. https://doi.org/10.1126/science.175.4027.1240.

54. Choy CA, Robison BH, Gagne TO, Erwin B, Firl E, Halden RU, et al. The vertical distribution and biological transport of marine microplastics across the epipelagic and mesopelagic water column. Sci Rep. 2019:9:7843.

55. Pabortsava K, Lampitt RS. High concentrations of plastic hidden beneath the surface of the Atlantic Ocean. Nat Commun. 2020;11(1):4073. https://doi. org/10.1038/s41467-020-17932-9.

56. Kaiser D, Kowalski N, Waniek JJ. Effects of biofouling on the sinking behavior of microplastics. Environ Res Lett. 2017;12(12):124003. https://doi.org/10.1 088/1748-9326/aа8e8b.

57. Long M, Moriceau B, Gallinari M, Lambert C, Huvet A, Raffray J, et al. Interactions between microplastics and phytoplankton aggregates: impact on their respective fates. Mar Chem. 2015;175:39-46. https://doi.org/10.101 6/j.marchem.2015.04.003.

58. Michels J, Stippkugel A, Lenz M, Wirtz K, Engel A. Rapid aggregation of biofilm-covered microplastics with marine biogenic particles. Proc R Soc B. 2018;285(1885):20181203. https://doi.org/10.1098/rspb.2018.1203.

59. Porter A, Lyons BP, Galloway TS, Lewis C. Role of marine snows in microplastic fate and bioavailability. Environ Sci Technol. 2018;52(12):7111-9. https://doi.org/10.1021/acs.est.8b01000.

60. Zhao S, Ward JE, Danley M, Mincer TJ. Field-based evidence for microplastic in marine aggregates and mussels: implications for trophic transfer. Environ Sci Technol. 2018;52(19):11038-48. https://doi.org/10.1021/acs.est.8b03467.

61. Katija K, Choy CA, Sherlock RE, Sherman AD, Robison BH. From the surface to the seafloor: how giant larvaceans transport microplastics into the deep sea. Sci Adv. 2017;3(8):e1700715. https://doi.org/10.1126/sciadv.1700715.

62. Enders K, Lenz R, Stedmon CA, Nielsen TG. Abundance, size and polymer composition of marine microplastics $\geq 10 \mu \mathrm{m}$ in the Atlantic Ocean and their modelled vertical distribution. Mar Pollut Bull. 2015;100(1):70-81. https://doi.org/10.1016/.jmarpolbul.2015.09.027.

63. Ter Halle A, Jeanneau L, Martignac M, Jardé E, Pedrono B, Brach L, et al. Nanoplastic in the North Atlantic subtropical gyre. Environ Sci Technol. 2017;51(23):13689-97. https://doi.org/10.1021/acs.est.7b03667.

\section{Publisher's Note}

Springer Nature remains neutral with regard to jurisdictional claims in published maps and institutional affiliations.

\section{Submit your manuscript to a SpringerOpen ${ }^{\circ}$ journal and benefit from:}

- Convenient online submission

- Rigorous peer review

- Open access: articles freely available online

- High visibility within the field

- Retaining the copyright to your article

Submit your next manuscript at $\boldsymbol{\nabla}$ springeropen.com 